\title{
Removal of Remazol brilliant violet textile dye by adsorption using rice hulls
}

\author{
Geyse Adriana Corrêa Ribeiro', Domingos Sérgio Araújo Silva², \\ Clayane Carvalho dos Santos ${ }^{1}$, Adriana Pires Vieira ${ }^{3}$, Cícero Wellington Brito Bezerra1*, \\ Auro Atsushi Tanaka ${ }^{1}$ and Sirlane Aparecida Abreu Santana ${ }^{1}$
}

\author{
${ }^{1}$ Inorganic Chemistry Laboratory \& Analytics, Department of Chemistry, Centro de Ciências Exatas e \\ Tecnologia - CCET, Universidade Federal do Maranhão - UFMA, Campus do Bacanga, São Luís, MA, Brazil \\ ${ }^{2}$ Department of Chemical Technology, Centro de Ciências Exatas e Tecnologia - CCET, Universidade \\ Federal do Maranhão - UFMA, Campus do Bacanga, São Luís, MA, Brazil \\ ${ }^{3}$ Institute of Chemistry, Universidade Estadual de Campinas - UNICAMP, Campinas, SP, Brazil \\ *cwb.bezerra@ufma.br
}

\begin{abstract}
The release of industrial effluents into the environment causes widespread contamination of aquatic systems. Adsorption is seen as one of the most promising treatment processes, and lignocellulosic materials have gained prominence as adsorbents. This study investigates the potential of rice hulls, either in natura or treated with nitric acid, as adsorbents for removal of the dye. The adsorbents were characterized by infrared spectroscopy, solid state ${ }^{13} \mathrm{C}-\mathrm{NMR}$, thermogravimetric analysis, and $\mathrm{pH}$ at point of zero charge. The dye adsorption experiments were carried out in batch mode, using different experimental conditions. The kinetic adsorption data could be fitted using the model of Elovich. The Freundlich model provided the best fit to the isothermal data. The thermodynamic parameters confirmed the spontaneity of the adsorption process. These adsorbents offer an alternative for dye removal, with advantages including biomass availability and low cost.
\end{abstract}

Keywords: adsorption, remazol, rice hull.

\section{Introduction}

The discharge of industrial effluents into the environment without adequate treatment is frequently a major problem, due to the problems of contamination of water resources. Many industries, such as those concerned with leather processing, rubber, paper, plastics, fabrics, and paints produce large volumes of wastewater containing various chemicals harmful to aquatic ecosystems ${ }^{[1-3]}$. Among these, in the absence of adequate wastewater treatment, textile manufacturers produce (during the dyeing step) effluent with persistent coloration, which can contaminate natural waters, interfering in the passage of solar radiation and impairing processes of photosynthesis ${ }^{[4,5]}$.

Many processes are used in the treatment of wastewater containing dyes, such as biological oxidation and chemical adsorption ${ }^{[5-7]}$, photoelectrochemical processes ${ }^{[8]}$, treatment with zero-valent iron ${ }^{[9]}$ and zero-valent iron $/ \mathrm{H}_{2} \mathrm{O}_{2}{ }^{[10]}$, heterogeneous photocatalysis combined with ozone treatment ${ }^{[11]}$, hydrogen peroxide combined with $\mathrm{UV}^{[12]}$, and others. However, many of these require appropriate conditions and have high operational costs. Adsorption has been shown to be very promising for the removal of textile dyes, since adsorbents can offer industrial practicality, low cost, high removal rates, and (in some cases) recovery of the species involved without losing their chemical identity ${ }^{[13]}$.

Adsorption is the removal of a chemical species from the fluid phase, with subsequent concentration on the surface of a substrate, usually a solid ${ }^{[14]}$. Adsorbents are generally highly porous and have a large surface area ${ }^{[15]}$. One widely used material is activated carbon, which offers high efficiency due to its structural characteristics, high surface area, and chemical nature ${ }^{[3]}$. However, its use has some disadvantages, such as low selectivity and efficiency for certain disperse dyes ${ }^{[16]}$, as well as losses during the recovery process ${ }^{[17]}$, resulting in a need to identify less expensive and more effective adsorbents. There are a variety of alternative low-cost materials that can be used for the removal of textile dyes, and other contaminants. Agricultural residues are an abundant and inexpensive renewable source of potential adsorbents. Examples include babassu coconut shell ${ }^{[18]}$, rice hull, rice straw ${ }^{[19,20]}$, and banana pseudostem ${ }^{[21]}$, amongst others. These agricultural residues can be used either in natura or modified with the insertion or release of active sites capable of improving the adsorption efficiency.

Rice hull is an agricultural waste biomass produced by the rice processing industry. This bulky byproduct represents about $23 \%$ of the weight of the grain ${ }^{[22]}$. Few options for the use of this material have been reported in the literature, and it is still common to see deposits of the waste in the open and on the banks of rivers ${ }^{[23]}$, where it takes about 5 years to decompose, while emitting a high volume of methane, a greenhouse gas that is also harmful to the ozone layer ${ }^{[24]}$. The aim of this study was therefore to analyze rice hull, in natura and treated with nitric acid, as an adsorbent for the removal of Remazol brilliant violet textile dye present in aqueous solutions. 


\section{Materials and Methods}

\subsection{Materials and reagents}

The rice hull used in this work was collected in São Bento city (Maranhão-BR). All reagents used were of analytical grade. The Remazol brilliant violet textile dye was produced by DyStar and provided by Toalhas São Carlos (São Paulo-BR). The purity of the dye was not specified. The chemical structure of Remazol brilliant violet dye is shown in Figure $1^{[18]}$

\subsection{Preparation of the adsorbent}

The rice hull was ground and washed with distilled water in a ratio of 10:1 (v/w) for $30 \mathrm{~min}$, with constant stirring, until the conductivity of the supernatant remained constant. The material was then dried at $333 \mathrm{~K}$ for $24 \mathrm{~h}$ and sieved to obtain the particle size range between 0.088 and $0.177 \mathrm{~mm}$. This in natura rice hull material was denoted RHI. Then, it was processed with acid, as described previously ${ }^{[25]}$, with small changes in contact time and temperature. RHI was placed in a solution of $2 \mathrm{~mol} \mathrm{~L}^{-1}$ nitric acid, at a ratio of $1: 200(\mathrm{w} / \mathrm{v})$, at $323 \pm 1 \mathrm{~K}$, for $5 \mathrm{~h}$ under constant stirring. It was then washed with distilled water until the supernatant conductivity remained constant, dried at $333 \mathrm{~K}$, and sieved to obtain the $0.088-0.177 \mathrm{~mm}$ particle size fraction. The treated rice hull was denoted $\mathrm{RHT}$.

\subsection{Characterization of the adsorbent}

The adsorbents were characterized by Fourier transform infrared spectroscopy (FTIR), ${ }^{13} \mathrm{C}$ nuclear magnetic resonance $\left({ }^{13} \mathrm{C}\right.$-NMR), thermogravimetric analysis (TGA), and $\mathrm{pH}$ at point of zero charge (pHpzc). The FTIR spectra in the $4000-400 \mathrm{~cm}^{-1}$ region were obtained using an MB series spectrometer Bomem-Hartmann \& Braun, and resolution of $4 \mathrm{~cm}^{-1}$. The $\mathrm{KBr}$ tablets were prepared using a press, by diluting the sample of interest in $\mathrm{KBr}$ at a ratio of $1: 100(\mathrm{w} / \mathrm{w})$. The ${ }^{13} \mathrm{C}$-NMR spectra were obtained using a Bruker AC300 spectrometer, with $7 \mathrm{~mm}$ rotor, cross polarization and magic angle spinning (CP-MAS), and a contact time of $3 \mathrm{~min}$. The repetition time was $3 \mathrm{~s}$ and the frequency was $4 \mathrm{kHz}$. The TGA were performed with a DuPont instrument (model 9900), heating from room temperature to $1273.15 \mathrm{~K}$ at $10 \mathrm{~K} \mathrm{~min}^{-1}$, under an inert argon atmosphere. The $\mathrm{pHpzc}$ values of the adsorbents were estimated by placing $100 \mathrm{mg}$ of the adsorbent (RHI or RHT) in contact with $25.0 \mathrm{~mL}$ of
$\mathrm{KCl}$ solution $\left(0.1 \mathrm{~mol} \mathrm{~L}^{-1}\right)$, with initial $\mathrm{pH}\left(\mathrm{pH}_{\mathrm{i}}\right)$ ranging from 1 to 12, previously adjusted with $\mathrm{HCl}$ or $\mathrm{NaOH}$. After $24 \mathrm{~h}$ of contact at room temperature and under constant agitation, the adsorbent was removed by filtration and the final $\mathrm{pH}\left(\mathrm{pH}_{\mathrm{f}}\right)$ of the supernatant was measured.

\section{$2.4 \mathrm{pH}$ study, adsorption kinetics and isotherms}

The study was carried out varying the initial $\mathrm{pH}$ of the Remazol brilliant violet dye solution. $100 \mathrm{mg}$ of adsorbent (RHI or RHT) was placed in contact with $25 \mathrm{ml}$ of dye solution $\left(100 \mathrm{mg} \mathrm{L}^{-1}\right)$ for $24 \mathrm{~h}$ at $298 \pm 1 \mathrm{~K}$, under continuous stirring. This test was performed at six $\mathrm{pH}$ values (initial $\mathrm{pH}$ between 1 and 6 , adjusted with $\mathrm{HCl}$ and $\mathrm{NaOH}$ ). To obtain the adsorption kinetics, $100 \mathrm{mg}$ of adsorbent was placed in contact with $25 \mathrm{~mL}$ of dye solution at two concentrations (100 and $1000 \mathrm{mg} \mathrm{L}^{-1}$ ), using the optimum $\mathrm{pH}$ (the $\mathrm{pH}$ at which greatest adsorption was observed in the $\mathrm{pH}$ study), with constant stirring at room temperature. The contact time was varied between 5 and $600 \mathrm{~min}$. Adsorption isotherms were obtained by placing $100 \mathrm{mg}$ of adsorbent in contact with $25 \mathrm{~mL}$ of dye solution at various concentrations ( 100 to $1000 \mathrm{mg} \mathrm{L}^{-1}$ ) and four temperatures (283, 298, 313, and $328 \pm 1 \mathrm{~K})$, using the optimum $\mathrm{pH}$ and stirring constantly during the equilibribration time. At the end of the contact time, the adsorbent was separated by centrifugation and the new dye concentration in the supernatant was determined with a UV-Vis spectrophotometer (model 2550, Shimadzu) fitted with a $1 \mathrm{~cm}$ optical path quartz cell, using the absorbance at $560 \mathrm{~nm}$. The amount of adsorbed dye, $\mathrm{q}\left(\mathrm{mg} \mathrm{g}^{-1}\right)$, was obtained using Equation $1^{[26]}$, where $\mathrm{C}_{\mathrm{i}}$ and $\mathrm{C}_{\mathrm{f}}\left(\mathrm{mg} \mathrm{L}^{-1}\right)$ are the initial and final dye concentrations, respectively, $\mathrm{m}(\mathrm{g})$ is the mass of adsorbent, and $\mathrm{V}(\mathrm{L})$ is the volume of dye solution.

$$
q=\frac{\left(C_{i}-C_{f}\right) V}{m}
$$

\section{Results and Discussion}

\subsection{Infrared spectroscopy}

Spectroscopy in the infrared region is a widely practiced characterization technique, because it allows qualitative evaluation of the presence of different functional groups.<smiles></smiles>

Figure 1. Chemical structure of Remazol brilliant violet dye. 
Figure 2 illustrates the vibrational spectra of all the materials studied. The large numbers of peaks found for the in natura and treated rice hulls indicate the heterogeneous nature of the adsorbents.

The IR spectrum of the dye (see Figures 1 and 2a) presented many absorption peaks, including those corresponding to phenolic $\mathrm{O}-\mathrm{H}$, secondary amide $\mathrm{N}-\mathrm{H}$ stretching, and aromatic $\mathrm{C}-\mathrm{H}$ at $3671-3047 \mathrm{~cm}^{-1}$; aliphatic $\mathrm{C}-\mathrm{H}_{\mathrm{n}}$ at around $2925 \mathrm{~cm}^{-1}$; amide $\mathrm{C}=\mathrm{O}$ stretching at $1639 \mathrm{~cm}^{-1} ; \mathrm{C}=\mathrm{C}$ stretching at $1532 \mathrm{~cm}^{-1} ; \mathrm{N}=\mathrm{N}$ stretching at $1436 \mathrm{~cm}^{-1}$; -SO (R-SO $\left.-\mathrm{R}\right)$ stretching at $1309 \mathrm{~cm}^{-1}$; - SO stretching of $\mathrm{R}-\mathrm{SO}_{3}^{-}$at $1207-989 \mathrm{~cm}^{-1}$; C-S stretching at $748 \mathrm{~cm}^{-1}$ (coupled with out-of-plane $\mathrm{C}-\mathrm{H}$ and $\mathrm{C}=\mathrm{C}$ bending) and at $626 \mathrm{~cm}^{-1[27,28]}$. The spectra for the adsorbents (Figures 2c and 2e) exhibited the characteristic bands of lignocellulosic materials reported in the literature ${ }^{[18,29-30]}$, and did not differ in terms of the nature of the functional groups present. Broad stretching bands occurred between 3100 and $3600 \mathrm{~cm}^{-1}$, indicating the presence of -OH groups on the surfaces of the matrices. These were mainly due to glycosidic structures, the presence of silanol groups ( $\mathrm{Si}-\mathrm{OH})$, and water adsorbed on the surfaces of the hulls ${ }^{[31]}$. A band between 2900-3000 $\mathrm{cm}^{-1}$ corresponded to $\mathrm{CH}$ stretching of the methyl groups that are common in the structures of lignocellulosic materials. A band located at $1730 \mathrm{~cm}^{-1}$ was characteristic of stretching of $\mathrm{C}=\mathrm{O}$ of ketones, aldehydes, and carboxylic acids. A band at $1640 \mathrm{~cm}^{-1}$ could be attributed to adsorbed water, while a band at $1500 \mathrm{~cm}^{-1}$ corresponded to aromatic $\mathrm{C}=\mathrm{C}$ vibrations. A band at $1370 \mathrm{~cm}^{-1}$ was due to $\mathrm{CH}$ plane deformation vibration, and a band at $1240 \mathrm{~cm}^{-1}$ was associated with $\mathrm{CO}$ stretching of the pyran ring. A band at $1060 \mathrm{~cm}^{-1}$ was due to the vibration of methoxyl (C-O-C) and $\beta-1,4$ bonds. Bands near $790 \mathrm{~cm}^{-1}$ were due to out-of-plane $\delta(\mathrm{CH})$ deformation of the aromatics present in lignin ${ }^{[32]}$. Comparison of the spectra for the in natura and treated adsorbents showed that the intensities of the bands at 3435 , 1734 , and $1067 \mathrm{~cm}^{-1}$ increased after treatment, as expected since these bands correspond to oxygen-containing groups (-OH, $-\mathrm{C}=\mathrm{O}$, and $-\mathrm{COC}-$, respectively) that may have been formed during the treatment with nitric acid ${ }^{[33]}$.

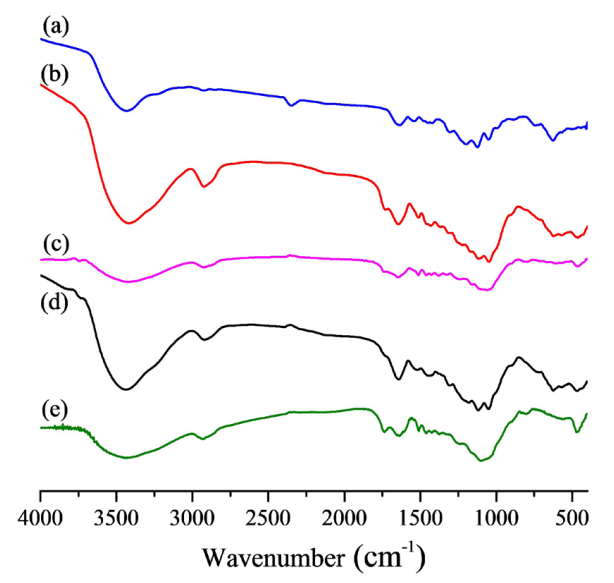

Figure 2. Infrared vibrational spectra of the RHI and RHT samples.

\subsection{Solid state ${ }^{13} \mathrm{C}$ nuclear magnetic resonance}

The solid state ${ }^{13} \mathrm{C}-\mathrm{NMR}$ spectra for the RHT and RHI matrices indicated the presence of structures of cellulose and its derivatives (Figure 3). A peak at $105 \mathrm{ppm}$ corresponded to the $\mathrm{C} 1$ carbon, with a large displacement due to the bonding to two oxygen atoms $(\mathrm{CH}(\mathrm{OR}) 2)$. Signals at 90 and $83 \mathrm{ppm}$ referred to $\mathrm{C} 4$, with a smaller displacement than $\mathrm{C} 1$ since the bond involves only one oxygen $(\mathrm{CH}-\mathrm{OR})^{[34,35]}$. A peak at $72 \mathrm{ppm}$ was related to the $\mathrm{C} 2, \mathrm{C} 3$, and $\mathrm{C} 5$ secondary carbons attached to the hydroxyl $(\mathrm{CH}-\mathrm{OH})$. Peaks at 64 and $62 \mathrm{ppm}$ were assigned to the $\mathrm{C} 6$ carbon, indicating regions of low crystallinity and amorphous character (see Figure 1A in the Appendix A) ${ }^{[36]}$, confirming this characteristic for both matrices. The presence of methyl groups and carboxyl carbon-carbon double bonds were indicated at 21 and $172 \mathrm{ppm}$, respectively. A signal corresponding to lignin guaiacyl methoxy groups was found at $55 \mathrm{ppm}$, and signals corresponding to aromatic carbons could be seen between 120 and $150 \mathrm{ppm}^{[37]}$.

Comparison of the ${ }^{13} \mathrm{C}$-NMR spectra of the different matrices revealed increases in the peaks relating to $\mathrm{C} 1$, C2, C3, C4, and C5 after treatment (RHT sample) (see also Table 1A in the Appendix A). This could be attributed to the effectiveness of the treatment with nitric acid, forming active adsorption sites and increased intensities of peaks related to carbon atoms with oxygen groups. These results corroborated those obtained in the characterization by infrared spectroscopy, which were also indicative of an increase in oxygen-containing groups after treatment.

\subsection{Thermogravimetric analysis}

Thermogravimetric analysis was used to determine the thermal stability of the adsorbents and provide quantitative data on mass loss according to temperature. The thermogravimetric (a) and derivative (b) curves obtained for the RHI and RHT adsorbents, under an inert argon atmosphere, are shown in Figure 4.

The adsorbents showed similar behavior in terms of thermal decomposition, remaining stable up to about $473 \mathrm{~K}$, as reported previously for other lignocellulosic materials ${ }^{[30]}$. Comparison of the percentage mass losses of the RHI and RHT adsorbents indicated that the in natura matrix showed greater weight loss corresponding to cellulose and hemicellulose, while the treated matrix showed greater loss of

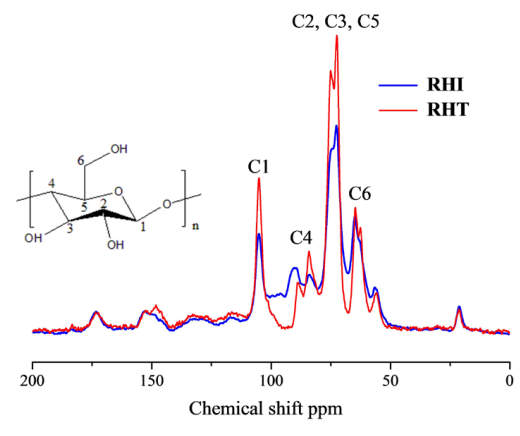

Figure 3. The solid state ${ }^{13} \mathrm{C}-\mathrm{NMR}$ spectra for the RHT and RHI. 
mass corresponding to lignin. The thermogravimetric curve showed three distinct stages of decomposition. The first, at around $373 \mathrm{~K}$, should not be taken into consideration in terms of thermal stability, because it was only due to the release of physically adsorbed water present on the surfaces of the adsorbents ${ }^{[38]}$. The second stage, between 473 and $623 \mathrm{~K}$, resulted in a greater loss of mass, due to the decomposition of hemicellulose and most of the cellulose. In the third stage (623-1043 K), which showed less mass loss than the previous stage, there was decomposition of lignin, which is structurally more stable than cellulose or hemicellulose ${ }^{[32]}$.

\section{4 pHpzc and effect of $\mathrm{pH}$}

The $\mathrm{pH}$ at the point of zero charge ( $\mathrm{pHpzc}$ ) is a parameter that indicates the $\mathrm{pH}$ value at which a particular solid does not have excess net charges on its surface. This parameter is important because it enables prediction of the surface charge of the adsorbent as a function of $\mathrm{pH}$, since at $\mathrm{pH}$ lower than the pHpzc, the surface charge of the solid is positive, while for $\mathrm{pH}$ values higher than the $\mathrm{pHpzc}$, the surface charge is negative. Figure 5 a shows a graph of the variation of $\Delta \mathrm{pH}\left(\mathrm{pH}_{\mathrm{i}}-\mathrm{pH}_{\mathrm{f}}\right)$, as a function of the initial $\mathrm{pH}$ $\left(\mathrm{pH}_{\mathrm{i}}\right)$, for the in natura and treated adsorbents.

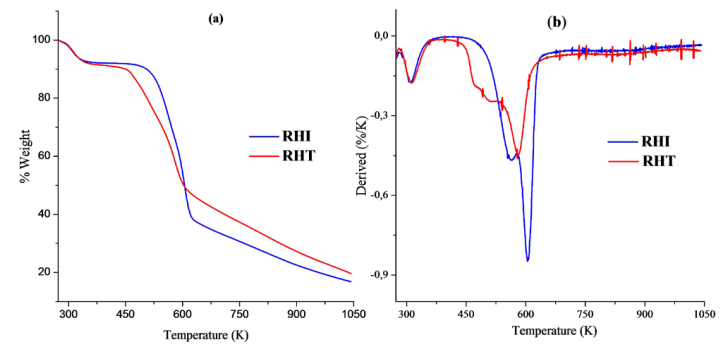

Figure 4. Thermogravimetric curves (a) and derived (b) of the RHI and RHT, obtained under an argon atmosphere, using a heating rate of $10 \mathrm{~K} \mathrm{~min}^{-1}$ in the temperature interval 298.15-1273.15 K.
The pHpzc values obtained for the RHI and RHT adsorbents were 5.3 and 3.8, respectively. Hence, below these $\mathrm{pH}$ values, the surfaces of the adsorbents would be positively charged, favoring anion adsorption, while at higher values, the surfaces would be negatively charged, favoring the adsorption of cations. The pHpzc value for RHI was very close to values reported in the literature for in natura rice hull (5.3) ${ }^{[19]}$ and babassu coconut epicarp $(6.7)^{[39,40]}$. In other work, it was found that in natura wood sawdust had a pHpzc of 5.3, which decreased to 4.0 after treatment with hydrochloric acid ${ }^{[41]}$. The decrease in the pHpzc value of the adsorbent after treatment is an indication that there were changes in the surface characteristics, with an increased number of protonated sites. This is supported by the increased prevalence of peaks related to oxygenated groups in the infrared and ${ }^{13} \mathrm{C}-\mathrm{NMR}$ spectra.

The $\mathrm{pH}$ of the system is an important element in the adsorption process, because $\mathrm{pH}$ change alters the chemical balance of the ionic groups present in the adsorbent and the dye, influencing the electrostatic interaction. Figure $5 \mathrm{~b}$ shows the removal percentages of Remazol brilliant violet dye by the RHT and RHI adsorbents. It can be seen that higher $\mathrm{pH}$ reduced adsorption of the dye, while at low $\mathrm{pH}$ there was greater protonation on the surfaces of the adsorbents, which favored anion removal.

The highest dye removal percentages were achieved at $\mathrm{pH} 1.0$ and 2.0. At $\mathrm{pH} 1.0$, the maximum amounts of dye adsorbed were 46.2 and $73.2 \%$ for RHI and RHT, respectively. Higher removal percentages of Remazol dyes at $\mathrm{pH} 1.0$ and 2.0 were observed previously using adsorbents such as babassu coconut mesocarp ${ }^{[42]}$ and rice hull ${ }^{[19]}$. Importantly, use of the RHT adsorbent significantly increased the percentage removal, compared to RHI, showing the effectiveness of the acid treatment. The adsorption by RHT improved between $\mathrm{pH} 3.0$ and $\mathrm{pH}$ 6.0, suggesting that in addition to electrostatic attraction, other interaction mechanisms were involved in the adsorption process, since a decreased removal capability was expected between these $\mathrm{pH}$ values, as found for the RHI adsorbent. Another interesting finding concerned the contribution of protonation to dye
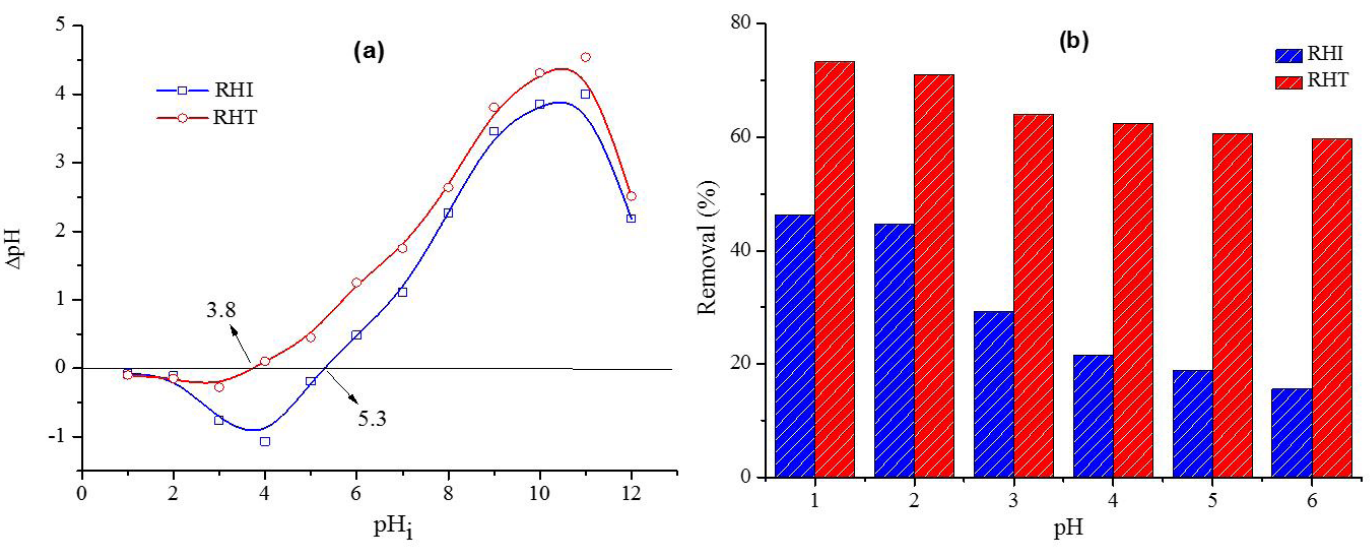

Figure 5. (a) pHpzc of the RHI and RHT, (b) Influence of $\mathrm{pH}$ on adsorption of Remazol brilliant violet dye by the RHI and RHT adsorbents $\left(\mathrm{m}=100 \mathrm{mg} ; \mathrm{Ci}=100 \mathrm{mg} \mathrm{L}^{-1}, \mathrm{t}=24 \mathrm{~h} ; \mathrm{T}=298 \pm 1 \mathrm{~K}\right)$. 
adsorption, with values of $66.3 \%$ and $18.4 \%$ obtained for RHI and RHT, respectively. These results provided further evidence of the effectiveness of the treatment, which resulted in dye removal being practically independent of the effect of protonation, due to the enhancement of other interactions that contributed to the adsorption.

\subsection{Adsorption kinetics}

Study of the adsorption kinetics is important, because it provides information about the mechanism of adsorption. This work considered the contact time between the adsorbent and the adsorbate required for the system to reach equilibrium. The adsorption kinetics depends on several factors, including the adsorbent mass, concentration of adsorbate, temperature, pressure, and stirring speed of the system. Figure 6 shows the adsorption kinetics for two concentrations of the Remazol brilliant violet dye (100 and $\left.1000 \mathrm{mg} \mathrm{L}^{-1}\right)$ at $\mathrm{pH} 2$ (defined as optimal in the adsorption experiments), together with the fits obtained with the Lagergren (Equation 2) ${ }^{[43]}$, Ho (Equation 3) ${ }^{[44]}$, and Elovich (Equation 4) ${ }^{[45]}$ kinetic models.

$$
\begin{aligned}
& q=q_{e}\left(1-\mathrm{e}^{-k_{1} t}\right) \\
& q=\frac{\left(q_{e}\right)^{2} k_{2} t}{1+q_{e} k_{2} t}
\end{aligned}
$$

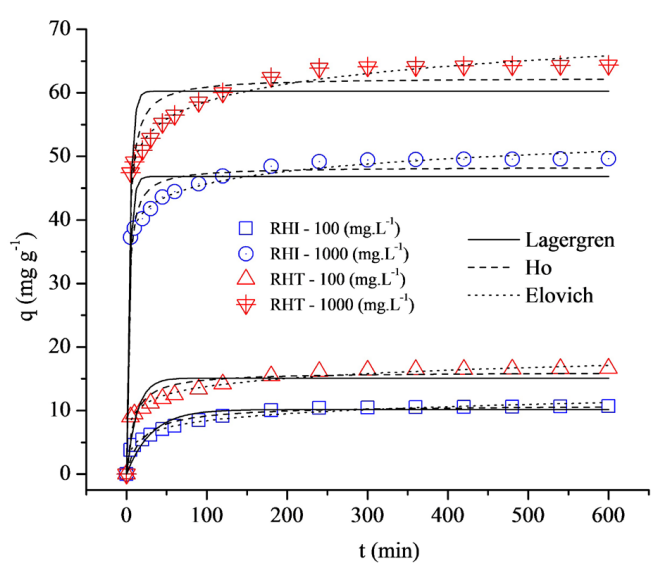

Figure 6. Adsorption kinetics of Remazol brilliant violet dye using RHI and RHT, at pH 2.0 and using initial dye concentrations of 100 and $1000 \mathrm{mg} \mathrm{L}^{-1}$.

$$
q=\frac{1}{\beta}(\ln (\alpha \beta)+\ln t)
$$

In the above equations, $\mathrm{q}_{\mathrm{e}}\left(\mathrm{mg} \mathrm{g}^{-1}\right)$ is the amount adsorbed at equilibrium, $\mathrm{k}_{1}\left(\mathrm{~min}^{-1}\right), \mathrm{k}_{2}\left(\mathrm{~g} \mathrm{mg}^{-1} \mathrm{~min}^{-1}\right)$, and $\alpha\left(\mathrm{mg} \mathrm{g}^{-1}\right.$ $\mathrm{min}^{-1}$ ) are the Lagergren, Ho, and Elovich adsorption rate constants, and $\beta\left(\mathrm{g} \mathrm{mg}^{-1}\right)$ is a parameter related to the activation energy. The equilibrium times were 180 and $240 \mathrm{~min}$ for dye concentrations of 100 and $1000 \mathrm{mg} \mathrm{L}^{-1}$, respectively. At the lower concentration, the equilibrium time was shorter due to the smaller number of interactions between the dye molecules and the active sites of the adsorbent. Most of the adsorption occurred within $60 \mathrm{~min}$, reflecting fast adsorption kinetics. The high adsorption rates in the early stages of the process were due to greater availability of active sites. Similar equilibrium times have been reported previously for the removal of Remazol dyes using lignocellulosic materials. Tunç et al. ${ }^{[4]]}$ used cotton stem bark to remove Remazol B black dye and obtained an equilibrium time of $300 \mathrm{~min}$.

The values of the fitting parameters for the Lagergren, Elovich, and Ho kinetic models are shown in Table 1. The closeness of $\mathrm{R}^{2}$ (coefficient of determination) to unity indicates the high levels of explanation provided by the models, with the best results obtained using the Elovich model. This model has been successfully used previously for adsorption by materials with heterogeneous surface energy, and allows for a gradual decrease in removal rate with increasing concentration ${ }^{[47]}$. The adsorbents used in this study presented several functional groups that could act as adsorption sites. Furthermore, Remazol brilliant violet dye also has many groups capable of interacting with adsorbents, so that the adsorption process was energetically heterogeneous, in agreement with the Elovich model.

\subsection{Adsorption isotherms}

After establishing the optimal $\mathrm{pH}$ and the equilibrium time, isotherms were constructed to determine the maximum amounts of dye that could be removed by the adsorbents. Figure 7 shows the dye adsorption isotherms for the RHI and RHT adsorbents, at four temperatures $(283,298$, 313 , and $328 \pm 1 \mathrm{~K})$. The isotherms can be represented by mathematical equations used to provide information on the mechanism of adsorption, surface properties, and the

\begin{tabular}{|c|c|c|c|c|c|}
\hline \multirow{2}{*}{ Models } & \multirow{2}{*}{ Parameters } & \multicolumn{2}{|c|}{ RHI } & \multicolumn{2}{|c|}{ RHT } \\
\hline & & $C_{i}=100 \mathrm{mg} \mathrm{L}^{-1}$ & $\mathrm{C}_{\mathrm{i}}=1000 \mathrm{mg} \mathrm{L}^{-1}$ & $\mathrm{C}_{\mathrm{i}}=100 \mathrm{mg} \mathrm{L}^{-1}$ & $C_{i}=1000 \mathrm{mg} \mathrm{L}^{-1}$ \\
\hline \multirow{3}{*}{ Lagergren } & $\mathrm{q}_{\mathrm{e}}\left(\mathrm{mg} \mathrm{g}^{-1}\right)$ & 10.17 & 46.83 & 15.12 & 60.26 \\
\hline & $\mathrm{k}_{1}\left(\min ^{-1}\right)$ & 0.033 & 0.261 & 0.079 & 0.249 \\
\hline & $\mathrm{R}^{2}$ & 0.9091 & 0.9208 & 0.7955 & 0.9031 \\
\hline \multirow{3}{*}{ Но } & $\mathrm{q}_{\mathrm{e}}\left(\mathrm{mg} \mathrm{g}^{-1}\right)$ & 10.88 & 48.35 & 16.06 & 62.40 \\
\hline & $\mathrm{k}_{2}\left(\mathrm{~g} \mathrm{mg}^{-1} \mathrm{~min}^{-1}\right)$ & 0.0049 & 0.0093 & 0.0074 & 0.0065 \\
\hline & $\mathrm{R}^{2}$ & 0.9684 & 0.9695 & 0.9157 & 0.9596 \\
\hline \multirow{3}{*}{ Elovich } & $\alpha\left(\mathrm{mg} \mathrm{g}^{-1} \mathrm{~min}^{-1}\right)$ & 3 & 253181 & 31 & 90545 \\
\hline & $\beta\left(\mathrm{g} \mathrm{mg}^{-1}\right)$ & 0.628 & 0.350 & 0.540 & 0.250 \\
\hline & $\mathrm{R}^{2}$ & 0.9845 & 0.9967 & 0.9900 & 0.9961 \\
\hline
\end{tabular}
affinity of the adsorbent for the adsorbate. Several models

Table 1. Fitting parameters for the kinetic models. 
have been reported in the literature, and in this work, the experimental data were tested using the Freundlich (Equation 5) ${ }^{[48]}$, Langmuir (Equation 6) ${ }^{[49]}$, and Temkin (Equation 7) ${ }^{[50]}$ models. The parameters of the models are given in Table 2.

$$
\begin{aligned}
& q_{e}=K_{F} C_{e q}^{1 / n} \\
& q_{e}=\frac{q_{m} C_{e q} K_{L}}{1+K_{L} C_{e q}} \\
& q_{e}=\mathrm{B} \cdot \ln \left(\mathrm{K}_{\mathrm{T}} \mathrm{C}_{\mathrm{eq}}\right)
\end{aligned}
$$

In the above equations, $\mathrm{q}_{\mathrm{m}}\left(\mathrm{mg} \mathrm{g}^{-1}\right)$ is the maximum amount of dye adsorbed; $\mathrm{K}_{\mathrm{F}}\left(\mathrm{L} \mathrm{mg}^{\mathrm{n}-1} \mathrm{~g}^{-\mathrm{n}}\right)^{1 / \mathrm{n}}, \mathrm{K}_{\mathrm{L}}\left(\mathrm{L} \mathrm{mg}^{-1}\right)$, and $\mathrm{K}_{\mathrm{T}}\left(\mathrm{L} \mathrm{mg}^{-1}\right)$ are constants of the Freundlich, Langmuir, and Temkin models, respectively; $n$ is a parameter related to the energy of the surface sites; $\mathrm{B}\left(\mathrm{mg} \mathrm{g}^{-1}\right)$ is a constant obtained from the expression $B=R T / b$, where $b$ is a parameter related to the heat of adsorption, $\mathrm{T}$ is the absolute temperature $(\mathrm{K})$, and $\mathrm{R}$ is the universal gas constant $\left(8.314 \mathrm{~J} \mathrm{~mol}^{-1} \mathrm{~K}^{-1}\right)$. The parameter, $\mathrm{n}$ describing the degree of heterogeneity of the system showed values between 1 and 5, which indicates favorable adsorption for both adsorption systems ${ }^{[51]}$. Application of the Freundlich model resulted in the highest value of the linear coefficient of determination $\left(\mathrm{R}^{2}\right)$, with values close to unity for all temperatures studied Table 2 .
Previous studies of lignocellulosic materials used for adsorption of Remazol brilliant violet have also found good fits using the Freundlich model. The materials tested were babassu coconut mesocarp ${ }^{[18]}$, and coconut straw ${ }^{[52]}$. The amount of dye adsorbed increased progressively with increasing temperature, suggesting that the system was endothermic. This behavior could be explained by factors such as increased mobility of the molecules present in the solution (increased kinetic energy caused by the temperature rise), increased diffusion of adsorbate on the surface of the adsorbent, and dilation of the pores of the adsorbent ${ }^{[53]}$.

\subsection{Thermodynamics of adsorption}

Knowledge of the adsorption thermodynamic parameters is important because it enables characterization of the process as spontaneous, exothermic, or endothermic, and provides information on the affinity of the adsorbent for the adsorbate. Additionally, these parameters can provide information concerning the heterogeneity of the surface of the adsorbent and whether the process involves physical or chemical adsorption. The thermodynamic parameters adsorption enthalpy $\left(\Delta \mathrm{H}^{\circ}\right)$, entropy $\left(\Delta \mathrm{S}^{\circ}\right)$, and Gibbs energy $\left(\Delta \mathrm{G}^{\mathrm{o}}\right)$ were obtained by linearization of the van't Hoff equation, according to Equations 8, 9, and $10^{[54]}$.

$$
\ln \mathrm{K}_{e q}=\frac{\ddot{\mathrm{AS}}{ }^{\circ}}{R}-\frac{\ddot{\mathrm{A}} \mathrm{H}^{\circ}}{R T}
$$
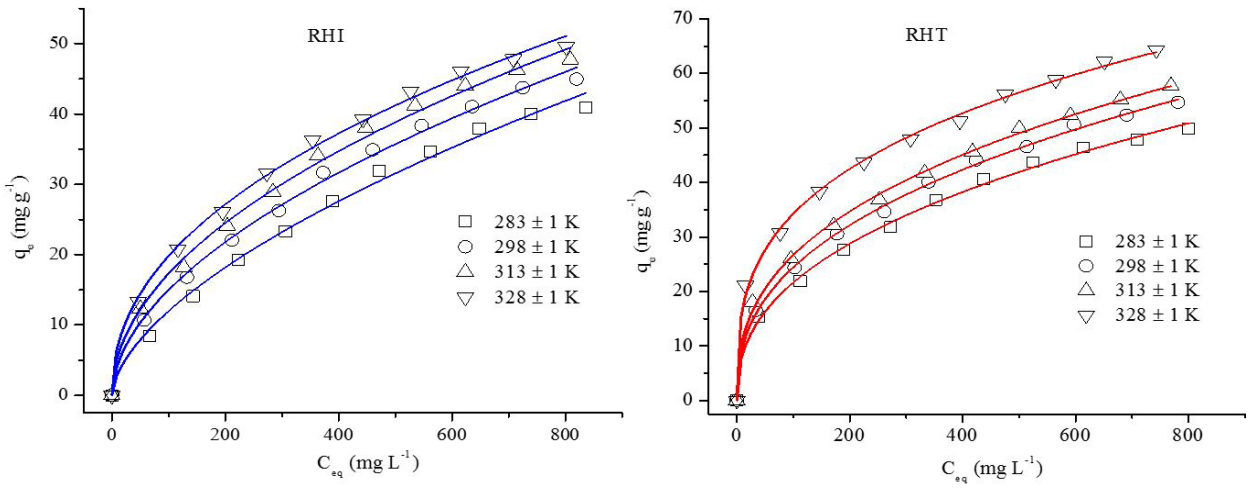

\begin{tabular}{|c|c|c|c|c|c|c|c|c|c|}
\hline \multirow{2}{*}{ Isotherms } & \multirow{2}{*}{ Parameters } & \multicolumn{4}{|c|}{ RHI } & \multicolumn{4}{|c|}{ RHT } \\
\hline & & $283 \mathrm{~K}$ & $298 \mathrm{~K}$ & $313 \mathrm{~K}$ & $328 \mathrm{~K}$ & $283 \mathrm{~K}$ & $298 \mathrm{~K}$ & $313 \mathrm{~K}$ & $328 \mathrm{~K}$ \\
\hline \multirow{3}{*}{ Freundlich } & $\mathrm{n}_{\mathrm{F}}$ & 1.663 & 1.854 & 1.990 & 2.196 & 2.433 & 2.519 & 2.647 & 3.211 \\
\hline & $\mathrm{K}_{\mathrm{F}}\left(\mathrm{Lmg}^{\mathrm{n}-1} \mathrm{~g}^{-\mathrm{n}}\right)^{1 / \mathrm{n}}$ & 0.751 & 1.250 & 1.709 & 2.432 & 3.260 & 3.924 & 4.685 & 8.156 \\
\hline & $\mathrm{R}^{2}$ & 0.9941 & 0.9965 & 0.9958 & 0.997 & 0.9972 & 0.9985 & 0.9983 & 0.9978 \\
\hline \multirow{3}{*}{ Langmuir } & $\mathrm{q}_{\mathrm{m}}\left(\mathrm{mg} \mathrm{g}^{-1}\right)$ & 71.16 & 68.63 & 68.48 & 65.20 & 61.41 & 65.07 & 66.49 & 67.87 \\
\hline & $\mathrm{K}_{\mathrm{L}}\left(\mathrm{L} \mathrm{mg}^{-1}\right)$ & 0.0017 & 0.0023 & 0.0028 & 0.0037 & 0.0047 & 0.0053 & 0.0060 & 0.0102 \\
\hline & $\mathrm{R}^{2}$ & 0.9974 & 0.9943 & 0.9914 & 0.9901 & 0.9774 & 0.9728 & 0.9606 & 0.9394 \\
\hline \multirow{3}{*}{ Temkin } & $\mathrm{B}\left(\mathrm{mg} \mathrm{g}^{-1}\right)$ & 13.80 & 13.74 & 13.77 & 13.44 & 12.13 & 12.68 & 12.40 & 11.52 \\
\hline & $\mathrm{K}_{\mathrm{T}}\left(\mathrm{L} \mathrm{mg}^{-1}\right)$ & 0.0214 & 0.0287 & 0.0354 & 0.0448 & 0.0654 & 0.0781 & 0.1036 & 0.2568 \\
\hline & $\mathrm{R}^{2}$ & 0.9777 & 0.9772 & 0.9757 & 0.9839 & 0.9771 & 0.9771 & 0.9708 & 0.9718 \\
\hline
\end{tabular}

Figure 7. Adsorption isotherms for Remazol brilliant violet dye using in natura (RHI) and treated (RHT) rice hulls as adsorbents.

Table 2. Parameters of the isotherm models used to fit the adsorption equilibrium data for removal of Remazol brilliant violet dye by the RHI and RHT adsorbents. Temperature error $= \pm 1 \mathrm{~K}$. 


$$
\begin{aligned}
& \ddot{\mathrm{AG}}^{\circ}=\ddot{\mathrm{A}} \mathrm{H}^{\circ}-\mathrm{T} \ddot{\mathrm{A}} \mathrm{S}^{\circ} \\
& \mathrm{K}_{e q}=\frac{q_{e}}{\mathrm{q}_{m}-q_{e}} \frac{1}{C_{e q}}
\end{aligned}
$$

In the above equations, $\mathrm{q}_{\mathrm{e}}$ is the amount adsorbed $\left(\mathrm{mg} \mathrm{g}^{-1}\right), \mathrm{q}_{\mathrm{m}}$ is the maximum amount adsorbed at each temperature $\left(\mathrm{mg} \mathrm{g}^{-1}\right), \mathrm{C}_{\mathrm{eq}}$ is the equilibrium concentration of the adsorbate $\left(\mathrm{mol} \mathrm{L}^{-1}\right), \mathrm{T}$ is the temperature of the adsorptive system $(\mathrm{K}), \mathrm{K}_{\mathrm{eq}}$ are equilibrium constants, and $\mathrm{R}$ is the gas constant $\left(8.314 \mathrm{~J} \mathrm{~K}^{-1} \mathrm{~mol}^{-1}\right)$. Figure 8 illustrates the linearization of the experimental data according to the van't Hoff equation, where linearity was observed between the points for the systems studied. The thermodynamic parameters for the adsorption of Remazol brilliant violet dye by the adsorbents are listed in Table 3 . Negative values of the Gibbs energy $\left(\Delta \mathrm{G}^{\circ}\right)$ indicated that the interactions between the dyes and the RHT and RHI adsorbents were spontaneous and favorable, because the lower the value of $\Delta \mathrm{G}^{\circ}$, the greater the driving force of the process, resulting in high adsorption ${ }^{[33]}$. This was supported by the more negative values of $\Delta \mathrm{G}^{\circ}$ for RHT, which also showed greater adsorption of the dye, compared to RHI. Positive enthalpy $\left(\Delta \mathrm{H}^{\circ}\right)$ values indicated the endothermic nature of all the adsorption processes, with the amount of dye adsorbed at equilibrium tending to increase with increasing temperature. The positive entropy $\left(\Delta S^{\circ}\right)$ values indicated that entropy increased during the adsorption process, so the process tended towards a higher degree of disorder.

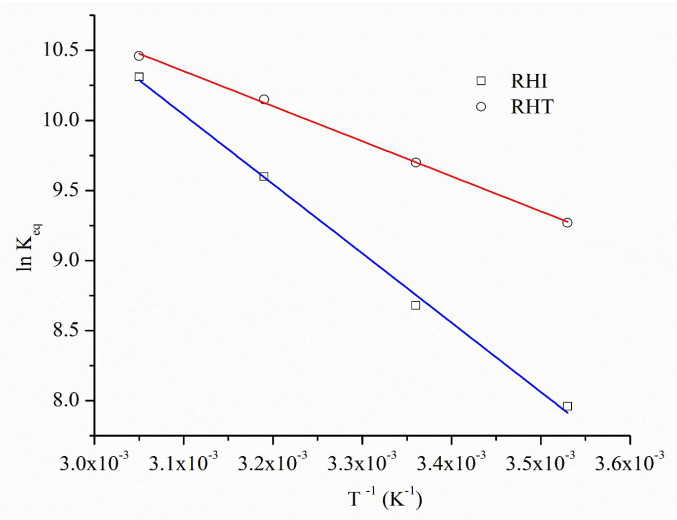

Figure 8. Van't Hoff plots for the adsorption of Remazol brilliant violet dye by the in natura (RHI) and treated (RHT) rice hull adsorbents.
Bekçi et al. ${ }^{[55]}$ reported that an enthalpy change of between 0 and $20 \mathrm{~kJ} \mathrm{~mol}^{-1}$ was characteristic of a physisorption process, while a change of between 80 and $400 \mathrm{~kJ} \mathrm{~mol}^{-1}$ reflected chemisorption. Alkan et al. ${ }^{[56]}$ found that an enthalpy change of between 40 and $120 \mathrm{~kJ} \mathrm{~mol}^{-1}$ characterized a chemisorption process. However, Zhou et al. ${ }^{[57]}$ considered that these ranges were not sufficient to confirm the type of adsorption. In fact, under favorable conditions, these processes can occur simultaneously or alternately ${ }^{[58]}$, but the values obtained suggested that adsorption of the dye by the adsorbents occurred mainly due to physisorption.

\subsection{Possible interactions between the dye and the adsorbents}

Elucidation of the mechanism of dye adsorption is a major challenge, as many interactions can occur during the adsorption process. Remazol Brilliant Violet is an anionic dye that contains a sulfonic group in its structure (which ionizes in aqueous solution, forming colored anions), together with aromatic rings. The RHT and RHI adsorbents were lignocellulosic materials composed primarily of cellulose, hemicellulose, and lignin. Characterization of the adsorbents revealed heterogeneous surfaces and the presence of hydroxyl and carbonyl groups.

Comparison of the IR spectra for the dye and the rice hull surfaces (Figures 2a, 2c, and 2e) revealed that they were very similar, with the exception of bands at $1639 \mathrm{~cm}^{-1}$ (amide I) and $626 \mathrm{~cm}^{-1}$ (C-S stretching), which were only present in the dye spectrum. These bands were present in the spectra for the dye-saturated biomasses (Figures $2 \mathrm{~b}$ and $2 \mathrm{~d}$ ), indicating that adsorption had occurred. Unfortunately, the characteristic $\mathrm{N}=\mathrm{N}$ stretching band of the dye was overlapped with the $\mathrm{C}-\mathrm{H}$ deformation vibration band, and could not be used for comparative analysis ${ }^{[27]}$. No other new bands were present in the spectra for the materials with adsorbed dye, suggesting similar predominant functional groups after adsorption. This was in agreement with the better definition and intensity of the IR bands for the materials with adsorbed dye, as well as with the estimated values of the thermodynamic parameters (which were indicative of physisorption ${ }^{[58]}$. Some of the well-defined bands, such as those at $1100-1300 \mathrm{~cm}^{-1}$, could be attributed to protonated sulfonic groups ${ }^{[27,59]}$ that probably resulted from interactions between the dye and the protonated surface, as illustrated in Figure 9.

The $\mathrm{pHpzc}$ values showed that at $\mathrm{pH}$ below 5.3 (RHI) and 3.8 (RHT), the surfaces of the adsorbents were positively

\begin{tabular}{|c|c|c|c|c|c|c|}
\hline Adsorbent & $\mathbf{T}(\mathbf{K})$ & $\mathrm{K}_{\mathrm{eq}} \times 10^{-4}$ & $\Delta \mathrm{G}^{\mathbf{0}}\left(\mathrm{kJ} \mathrm{mol}^{-1}\right)$ & $\Delta \mathrm{H}^{\mathbf{0}}\left(\mathrm{kJ} \mathrm{mol}^{-1}\right)$ & $\Delta \mathrm{S}^{\mathbf{0}}\left(\mathrm{J} \mathrm{mol}^{-1} \mathrm{~K}^{-1}\right)$ & $\mathbf{R}^{2}$ \\
\hline \multirow{4}{*}{ RHI } & $283 \pm 1$ & 0.29 & -18.60 & \multirow{4}{*}{40.95} & \multirow{4}{*}{210.41} & \multirow{4}{*}{0.9978} \\
\hline & $298 \pm 1$ & 0.59 & -21.75 & & & \\
\hline & $313 \pm 1$ & 1.48 & -24.91 & & & \\
\hline & $328 \pm 1$ & 3.00 & -28.07 & & & \\
\hline \multirow{4}{*}{ RHT } & $283 \pm 1$ & 1.06 & -21.81 & \multirow{4}{*}{20.71} & \multirow{4}{*}{150.27} & \multirow{4}{*}{0.9989} \\
\hline & $298 \pm 1$ & 1.63 & -24.07 & & & \\
\hline & $313 \pm 1$ & 2.56 & -26.32 & & & \\
\hline & $328 \pm 1$ & 3.49 & -28.58 & & & \\
\hline
\end{tabular}

Table 3. Thermodynamic parameters for the adsorption of Remazol brilliant violet dye by the RHI and RHT adsorbents. 


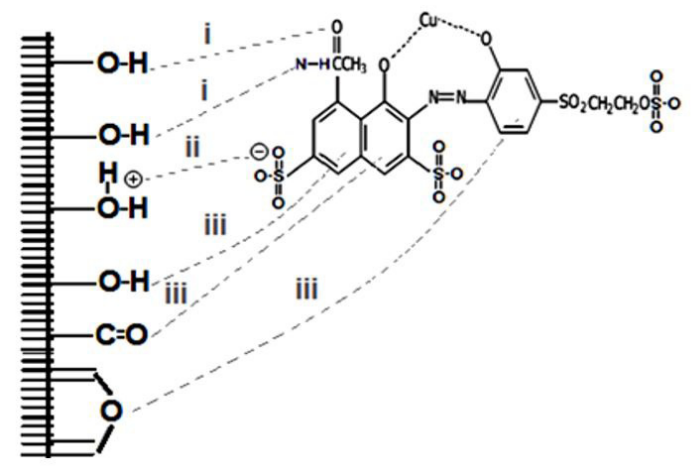

Figure 9. Possible adsorbent-dye interactions: (i) hydrogen bonds; (ii) electrostatic attraction; (iii) $\pi$ electron resonance.

charged, with the presence of $\mathrm{H}^{+}$ions favoring adsorption of anionic species such as the dyes studied here. This was supported by the results obtained in the study of the influence of $\mathrm{pH}$ on the adsorption, with greater removal achieved at $\mathrm{pH} 1$ and 2. These findings indicated that the mechanism of adsorption of the dye by the adsorbent occurred due to electrostatic attraction, with the adsorbents being protonated in an acid medium, hence attracting the negatively charged sulfonic groups of the dye.

The treated adsorbent showed greater dye removal efficiency, compared to the in natura material, especially at less acidic $\mathrm{pH}(\mathrm{pH} 3-6)$, where the percentage removal remained essentially constant. However, a smaller influence of protonation was observed for the treated adsorbent. These findings confirmed that in addition to electrostatic attraction, other interactions were involved in the adsorption systems studied. The FTIR results showed that carboxyl, hydroxyl, and aromatic carbon functional groups could participate in dye adsorption. Considering all the information obtained in the experiments, three possible interaction mechanisms $\mathrm{s}^{[50,60]}$ can be proposed for the adsorption of Remazol Brilliant Violet dye by the adsorbents at $\mathrm{pH}$ 2: (i) hydrogen bonding, (ii) electrostatic attraction, and (iii) $\pi$ electron resonance (Figure 9).

\section{Conclusions}

The surface of rice hull was successfully modified by treatment with nitric acid, resulting in a decrease in the point of zero charge (pHpzc). Infrared and ${ }^{13} \mathrm{C}-\mathrm{NMR}$ analyses showed that oxygenated groups were introduced in the rice hull surface after treatment. Thermogravimetric analysis indicated that the matrix remained stable up to temperatures close to $473 \mathrm{~K}$, and that the treated adsorbent showed greater weight loss due to the decomposition of lignin. The points of zero charge (pHpzc) were $\mathrm{pH} 5.3$ and $\mathrm{pH} 3.8$ for the in natura and treated materials, respectively. Below the pHpcz, the surface was positively charged, favoring adsorption of the anionic dye.

Kinetic studies revealed that adsorption equilibrium was achieved within around $240 \mathrm{~min}$. The Elovich kinetic model provided the best fit to the experimental data for adsorption of the dye, for the two concentrations employed here. The adsorption isotherms obtained for different temperatures showed that the removal efficiency increased with increasing temperature. The Freundlich isotherm model provided the best explanation of the experimental results for adsorption of the dye. The thermodynamic parameters $\left(\Delta \mathrm{G}^{\circ}, \Delta \mathrm{H}^{\circ}\right.$, and $\left.\Delta \mathrm{S}^{\circ}\right)$ obtained for these adsorption systems (at the temperatures studied) revealed that the reactions were spontaneous, energetically favorable, and endothermic, with a high degree of disorder.

\section{Acknowledgments}

The authors are grateful to FAPEMA, CNPq and CAPES for financial support.

\section{References}

1. Zeng, S., Duan, S., Tang, R., Li, L., Liu, C., \& Sun, D. (2014) Magnetically separable $\mathrm{Ni}_{0.6} \mathrm{Fe}_{2.4} \mathrm{O}_{4}$ nanoparticles as an effective adsorbent for dye removal: Synthesis and study on the kinetic and thermodynamic behaviors for dye adsorption. Chemical Engineering Journal, 258, 218-228. http://dx.doi.org/10.1016/j. cej.2014.07.093

2. Peng, X., Huang, D., Odoom-Wubah, T., Fu, D., Huang, J., \& Qin, Q. (2014). Adsorption of anionic and cationic dyes on ferromagnetic ordered mesoporous carbon from aqueous solution: equilibrium, thermodynamic and kinetics. Journal of Colloid and Interface Science, 430, 272-282. PMid:24973701. http://dx.doi.org/10.1016/j.jcis.2014.05.035.

3. Crini, G. (2006). Non-conventional low-cost adsorbents for dye removal: A review. Bioresource Technology, 97(9), 1061-1085. PMid:15993052. http://dx.doi.org/10.1016/j. biortech.2005.05.001.

4. Durán-Jiménez, G., Hernández-Montoya, V., Montes-Morán, M. A., Bonilla-Petriciolet, A., \& Rangel-Vázquez, N. A. (2014). Adsorption of dyes with different molecular properties on activated carbons prepared from lignocellulosic wastes by Taguchi method. Microporous and Mesoporous Materials, 199 , 99-107. http://dx.doi.org/10.1016/j.micromeso.2014.08.013.

5. Guaratini, C. C. I., \& Zanoni, M. V. B. (2000). Corantes Têxteis. Quimica Nova, 23(1), 71-78. http://dx.doi.org/10.1590/S010040422000000100013.

6. Sathishkumar, P., Mani, A., \& Thayumanavan, P. (2012). Utilization of agro-industrial waste Jatropha curcas pods as an activated carbon for the adsorption of reactive dye Remazol Brilliant Blue R (RBBR). J. Journal of Cleaner Production, 22(1), 67-75. http://dx.doi.org/10.1016/j.jclepro.2011.09.017.

7. Zhong, Z.-Y., Yang, Q., Li, X.-M., Luo, K., Liu, Y., \& Zeng, G.-M. (2012). Preparation of peanut hull-based activated carbon by microwave-induced phosphoric acid activation and its application in Remazol Brilliant Blue R adsorption. Industrial Crops and Products, 37(1), 178-185. http://dx.doi. org/10.1016/j.indcrop.2011.12.015.

8. Bertazzoli, R., \& Pelegrini, R. (2002). Descoloração e degradação de poluentes orgânicos em soluções aquosas através do processo fotoeletroquímico. Quimica Nova, 25(3), 477-482. http://dx.doi.org/10.1590/S0100-40422002000300022.

9. Freire, R. S., \& Pereira, W. S. (2005). Ferro zero: Uma nova abordagem para o tratamento de águas contaminadas com compostos orgânicos poluentes. Quimica Nova, 28(1), 130136. http://dx.doi.org/10.1590/S0100-40422005000100022.

10. Souza, C. R. L., \& Peralta-Zamora, P. (2005). Degradação de corantes reativos pelo sistema ferro metálico/peróxido de hidrogênio. Quimica Nova, 28(2), 226-228. http://dx.doi. org/10.1590/S0100-40422005000200011. 
11. Moraes, S. G., Freire, R. S., \& Durán, N. (2000). Degradation and toxicity reduction of textile effluent by combined photocatalytic and ozonation processes. Chemosphere, 40(4), 369-373. PMid:10665401. http://dx.doi.org/10.1016/S00456535(99)00239-8.

12. Shu, H.-Y., \& Chang, M.-C. (2005). Decolorization effects of six azo dyes by $\mathrm{O}_{3}, \mathrm{UV} / \mathrm{O}_{3}$ and $\mathrm{UV} / \mathrm{H}_{2} \mathrm{O}_{2}$ processes. Dyes and Pigments, 65(1), 25-31. http://dx.doi.org/10.1016/j. dyepig.2004.06.014.

13. Dallago, R. M., Smaniotto, A., \& Oliveira, L. C. A. (2005). Resíduos sólidos de curtumes como adsorventes para a remoção de corantes em meio aquoso. Quimica Nova, 28(3), 433-437. http://dx.doi.org/10.1590/S0100-40422005000300013.

14. Adamson, A. W., \& Gast, A. P. (1997). Physical chemistry of surfaces. New York: John Wiley \& Sons.

15. Mak, S.-Y., \& Chen, D.-H. (2004). Fast adsorption of methylene blue on polyacrylic acid-bond iron oxide magnetic nanoparticles. Dyes and Pigments, 61(1), 93-98. http://dx.doi.org/10.1016/j. dyepig.2003.10.008.

16. Babel, S., \& Kurniawan, T. A. (2003). Low-cost adsorbents for heavy metals uptake from contaminated water: a review. Journal of Hazardous Materials, 97(1-3), 219-243. PMid:12573840. http://dx.doi.org/10.1016/S0304-3894(02)00263-7.

17. McKay, G. (1980). Colour removal by adsorption. American Dyestuff Reporter, 69, 38. http://dx.doi.org/10.1016/00431354(88)90165-0.

18. Vieira, A. P., Santana, S. A. A., Bezerra, C. W. B., Silva, H. A. S. S., Chaves, J. A. P., Melo, J. C. P., Silva, E. C., Fo., \& Airoldi, C. (2009). Kinetics and thermodynamics of textile dye adsorption from aqueous solutions using babassu coconut mesocarp. Journal of Hazardous Materials, 166(23), 1272-1278. PMid:19150173. http://dx.doi.org/10.1016/j. jhazmat.2008.12.043.

19. Costa, E. P., Santana, S. A. A., Bezerra, C. W. B., Silva, H. A. S., \& Schultz, M. S. (2009). Uso da casca de arroz como adsorvente na remoção do Corante têxtil vermelho remazol 5R. Caderno de Pesquisa, 16(2), 44-48.

20. Gong, R., Jin, Y., Chen, F., Chen, J., \& Zhili, L. (2006). Enhanced malachite green removal from aqueous solution by citric acid modified rice straw. Journal of Hazardous Materials, 137(2), 865-870. PMid:16621265. http://dx.doi.org/10.1016/j. jhazmat.2006.03.010.

21. Rodrigues, N. F. M., Santana, S. A. A., Bezerra, C. W. B., Silva, H. A. S., Melo, J. C. P., Vieira, A. P., Airoldi, C., \& Silva, E. C., Fo., (2013). New chemical organic anhydride immobilization process used on banana pseudostems: a biopolymer for cation removal. Journal of Industrial and Engineering Chemistry, 52(32), 11007-11015. http://dx.doi.org/10.1021/ie303409b.

22. Della, V. P., Kuhn, I., \& Hotza, D. (2001). Caracterização de cinza de casca de arroz para uso como matéria-prima na fabricação de refratários de sílica. Quimica Nova, 24(6), 778782. http://dx.doi.org/10.1590/S0100-40422001000600013.

23. Della, V. P., Kuhn, I., \& Hotza, D. (2006). Estudo comparativo entre sílica obtida por lixívia ácida da casca de arroz e sílica obtida por tratamento térmico da cinza de casca de arroz. Quimica Nova, 29(6), 1175-1179. http://dx.doi.org/10.1590/ S0100-40422006000600005.

24. Dyominov, I. G., \& Zadorozhny, A. M. (2005). Greenhouse gases and recovery of the Earth's ozone layer. Advances in Space Research, 35(8), 1369-1374. http://dx.doi.org/10.1016/j. asr.2005.04.090.

25. Ponnusami, V., Krithika, V., Madhuram, R., \& Srivastava, S. N. (2007). Biosorption of reactive dye using acid-treated rice husk:Factorial design analysis. Journal of Hazardous Materials, 142(1-2), 397-403. PMid:17011118. http://dx.doi. org/10.1016/j.jhazmat.2006.08.040.
26. Chiou, M. S., Ho, P. Y., \& Li, H. Y. (2004). Adsorption of anionic dyes in acid solutions using chemically cross-linked chitosan beads. Dyes and Pigments, 60(1), 69-84. http://dx.doi. org/10.1016/S0143-7208(03)00140-2.

27. Yuen, C. W. M., Ku, S. K. A., Choi, P. S. R., Kan, C. W., \& Tsang, S. Y. (2005). Determining functional groups of commercially available ink-jet printing reactive dyes using infrared spectroscopy. Research Journal of Textile and Apparel, 9, 26-38.

28. Aboudan, M., \& Kassab, R. (2015). Synthesis of new azo dyes derived from 2,7-dihydroxynaphthalene. International Journal of Academic Scientific Research, 3, 143-149.

29. Noda, I. (1993). Generalized two-dimensional correlation method applicable to infrared, raman, and other types of spectroscopy. Applied Spectroscopy, 47(9), 1329-1336. http:// dx.doi.org/10.1366/0003702934067694.

30. Gupta, V. K., Pathania, D., Sharma, S., Agarwal, S., \& Singh, P. (2013). Remediation of noxious chromium (VI) utilizing acrylic acid grafted lignocellulosic adsorbent. Journal of Molecular Liquids, 177, 343-352. http://dx.doi.org/10.1016/j. molliq.2012.10.017

31. Kamath, S. R., \& Proctor, A. (1998). Sílica gel from rice hull ash: preparation and characterization. Cereal Chemistry, 75(4), 484-487. http://dx.doi.org/10.1094/CCHEM.1998.75.4.484.

32. Tserki, V., Matzinos, P., Kokkou, S., \& Panayiotou, C. (2005). Novel biodegradable composites based on treated lignocellulosic waste flour as filler. Part I. Surface chemical modification and characterization of waste flour. Composites. Part A, Applied Science and Manufacturing, 36(7), 965-974. http://dx.doi. org/10.1016/j.compositesa.2004.11.010.

33. Fras, L., Johansson, L. S., Stenius, P., Laine, J., Stana-Kleinschek, K., \& Ribitsch, V. (2005). Analysis of the oxidation of cellulose fibres by titration and XPS. Colloids and Surfaces, 260(1-3), 101-108. http://dx.doi.org/10.1016/j.colsurfa.2005.01.035.

34. Smits, J., \& Grieken, R. V. (1981). Enrichment of trace anions from water with 2,2'-diaminodiethylamine cellulose filters. Analytica Chimica Acta, 123, 9-17. http://dx.doi.org/10.1016/ S0003-2670(01)83152-4.

35. Liu, C. F., Sun, R. C., Zhang, A. P., \& Ren, J. L. (2007). Preparation of sugarcane bagasse cellulosic phthalate using an ionic liquid as reaction medium. Carbohydrate Polymers, 68(1), 17-25. http://dx.doi.org/10.1016/j.carbpol.2006.07.002.

36. Chang, S. T., \& Chang, H. T. (2001). Comparisons of the photostability of esterified wood. Polymer Degradation \& Stability, 71(2), 261-266. http://dx.doi.org/10.1016/S01413910(00)00171-3.

37. Tarley, C. R. T., \& Arruda, M. A. Z. (2004). Biosorption of heavy metals using rice milling byproducts. Characterization and application for removal of metals from aqueous effluents. Chemosphere, 54(7), 987-995. PMid:14637356. http://dx.doi. org/10.1016/j.chemosphere.2003.09.001.

38. Han, R., Zhang, L., Song, C., Zhang, M., Zhu, H., \& Zhang, L. J. (2010). Characterization of modified wheat straw, kinetic and equilibrium study about copper ion and methylene blue adsorption in batch mode. Carbohydrate Polymers, 79(4), 1140-1149. http://dx.doi.org/10.1016/j.carbpol.2009.10.054.

39. Holanda, C. A., Sousa, J. L., Santos, C. C., Santos, H. A. S., Santana, S. A. A., Costa, M. C. P., Schultz, M. S., \& Bezerra, C. W. B. (2015). Remoção Do Corante Têxtil Turquesa De Remazol Empregando Aguapé (Eichhornia Crassipes) Como Adsorvente. Electronic Journal of Chemistry, 7(2), 141-154.

40. Vieira, A. P., Santana, S. A. A., Bezerra, C. W. B., Silva, H. A. S. S., Chaves, J. A. P., Melo, J. C. P., Silva, E. C., Fo., \& Airoldi, C. (2011). Removal of textile dyes from aqueous solution by babassu coconut epicarp (Orbignya speciosa). 
Chemical Engineering Journal, 173(2), 334-340. http://dx.doi. org/10.1016/j.cej.2011.07.043.

41. Janos, P., Coskun, S., Pilarová, V., \& Rejnek, J. (2009). Removal of basic (Methylene Blue) and acid (Egacid Orange) dyes from waters by sorption on chemically treated wood shavings. Bioresource Technology, 100(3), 1450-1453. PMid:18848777. http://dx.doi.org/10.1016/j.biortech.2008.06.069.

42. Vieira, A. P., Santana, S. A. A., Bezerra, C. W. B., Silva, H. A. S. S., Chaves, J. A. P., Melo, J. C. P., Silva, E. C., Fo., \& Airoldi, C. (2011). Epicarp and Mesocarp of Babassu (Orbignya speciosa): Characterization and Application in Copper Phtalocyanine Dye Removal. Journal of the Brazilian Chemical Society, 22(1), 21-29. http://dx.doi.org/10.1590/ S0103-50532011000100003.

43. Lagergren, S. (1898). About the theory of so-called adsorption of soluble substances. Handlingar, 24, 1-39.

44. Ho, Y., \& McKay, G. (1998). The kinetics of sorption of basic dyes from aqueous solution by sphagnum moss peat. Canadian Society for Chemical Engineering, 76(4), 822-827. http://dx.doi.org/10.1002/cjce.5450760419.

45. Peers, A. M. (1965). Elovich adsorption kinetics and the heterogeneous surface. Journal of Catalysis, 4(4), 499-503. http://dx.doi.org/10.1016/0021-9517(65)90054-0.

46. Tunç, O., Tanaci, H., \& Aksu, Z. (2009). Potential use of cotton plant wastes for the removal of Remazol Black B reactive dye. Journal of Hazardous Materials, 163(1), 187-198. PMid:18675510. http://dx.doi.org/10.1016/j.jhazmat.2008.06.078.

47. Ai, L., Zhang, C., \& Meng, L. (2011). Adsorption of Methyl Orange from Aqueous Solution on Hydrothermal Synthesized Mg-Al Layered Double Hydroxide. Journal of Chemical \& Engineering Data, 56(11), 4217-4225. http://dx.doi.org/10.1021/ je200743u.

48. Freundlich, H. M. F. (1906). Over the adsorption in solution. Journal of Physical Chemistry, 57, 385-470.

49. Langmuir, I. (1918). The adsorption of gases on plane surfaces of glass, mica and platinum. Journal of the American Chemical Society, 40(9), 1361-1403. http://dx.doi.org/10.1021/ja02242a004.

50. Temkin, M. I. (1972). Theoretical models of the kinetics of heterogeneous catalytic reactions. Kinetics and Catalysis, 13, 555-565. http://dx.doi.org/10.1021/cr00035a010.

51. Achak, M., Hafidi, A., Ouazzani, N., Sayadi, S., \& Mandi, L. (2009). Low cost biosorbent "banana peel" for the removal of phenolic compounds from olive mill wastewater: Kinetic and equilibrium studies. Journal of Hazardous Materials, 166(1), 117-125. PMid:19144464. http://dx.doi.org/10.1016/j. jhazmat.2008.11.036.
52. Namasivayam, C., Kumar, M. D., Selvi, K., Begum, R. A., Vanathi, T., \& Yamuna, R. T. (2001). Waste coir pith-a potential biomass for the treatment of dyeing wastewaters. Biomass and Bioenergy, 21(6), 477-483. http://dx.doi.org/10.1016/ S0961-9534(01)00052-6.

53. Saeed, A., Sharif, M., \& Iqbal, M. (2010). Application potential of grapefruit peel as dye sorbent: kinetics, equilibrium and mechanism of crystal violet adsorption. Journal of Hazardous Materials, 179(1-3), 564-572. PMid:20381962. http://dx.doi. org/10.1016/j.jhazmat.2010.03.041.

54. Wang, L., \& Li, J. (2013). Adsorption of C.I. Reactive Red 228 dye from aqueous solution by modified cellulose from flax shive: Kinetics, equilibrium, and thermodynamics. Industrial Crops and Products, 42, 153-158. http://dx.doi.org/10.1016/j. indcrop.2012.05.031.

55. Bekçi, Z., Seki, Y., \& Cavas, L. (2009). Removal of malachite green by using an invasive marine alga Caulerpa racemosa var. Cylindracea. Journal of Hazardous Materials, 161(2-3), 1454-1460. PMid:18562093. http://dx.doi.org/10.1016/j. jhazmat.2008.04.125.

56. Alkan, M., Demirbas, O., Celikcapa, S., \& Dogan, M. (2004). Sorption of acid red 57 from aqueous solution onto sepiolite. Journal of Hazardous Materials, 116(1-2), 135-145. PMid:15561372. http://dx.doi.org/10.1016/j.jhazmat.2004.08.003.

57. Zhou, Y. T., Nie, C. B.-W., \& Zhu, J. C. (2009). Adsorption mechanism of $\mathrm{Cu}^{2+}$ from aqueous solution by chitosan-coated magnetic nanoparticles modified with $\alpha$-ketoglutaric acid. Colloids and Surfaces. B, Biointerfaces, 74(1), 244-252. PMid: 19683900. http://dx.doi.org/10.1016/j.colsurfb.2009.07.026.

58. Dabrowski, A. (2001). Adsorption - from theory to practice. Advances in Colloid and Interface Science, 93(1-3), 135-224. PMid:11591108. http://dx.doi.org/10.1016/S0001-8686(00)000828.

59. Silverstein, R. M., Bassler, G. C., \& Morrill, T. C. (1991). Spectrometric identification of organic compounds. New York: John Wiley \& Sons.

60. Chatterjee, S., Chatterjee, B. P., \& Guha, A. K. (2007). Adsorptive removal of congo red, a carcinogenic textile dye by chitosan hydrobeads: Binding mechanism, equilibrium and kinetics. Colloids and Surfaces. A, Physicochemical and Engineering Aspects, 299(1-3), 146-152. http://dx.doi. org/10.1016/j.colsurfa.2006.11.036.

Received: Nov. 09, 2015

Revised: Apr. 05, 2016

Accepted: Apr. 28, 2016 
Ribeiro, G. A. C., Silva, D. S. A., Santos, C. C., Vieira, A. P., Bezerra, C. W. B., Tanaka, A. A., \& Santana, S. A. A.

Appendix A. Aditional materials.

Table 1A. Percentages of carbon $(\mathrm{C})$, hydrogen $(\mathrm{H})$, and nitrogen $(\mathrm{N})$ in the in natura $(\mathrm{RHI})$ and treated (RHT) adsorbents.

\begin{tabular}{cccc}
\hline Adsorbent & $\mathbf{\% C}$ & $\mathbf{\% H}$ & $\mathbf{\% N}$ \\
\hline RHI & 35.87 & 5.04 & 0.54 \\
RHT & 39.73 & 5.37 & 1.46 \\
Difference & 3.86 & 0.33 & 0.92 \\
\hline
\end{tabular}

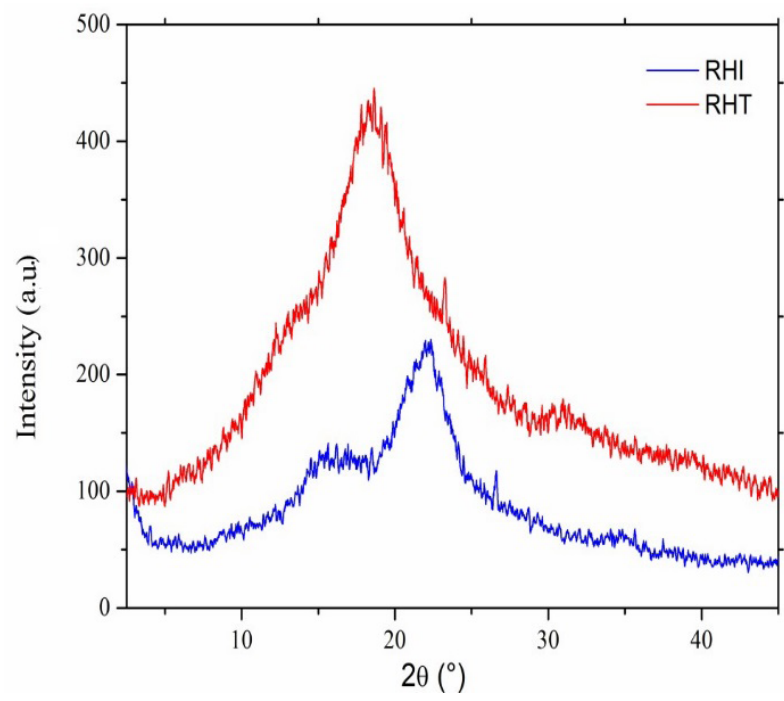

Figure 1A. X-ray diffractograms of the in natura (RHI) and treated (RHT) rice hulls. 